\title{
Bactericidal potential of silver nanoparticles synthesized using cell-free extract of Comamonas acidovorans: in vitro and in silico approaches
}

\author{
Darshan M. Rudakiya ${ }^{1}$ (D) Kirti Pawar ${ }^{2}$
}

Received: 20 October 2016/Accepted: 7 December 2016/Published online: 29 May 2017

(C) Springer-Verlag Berlin Heidelberg 2017

\begin{abstract}
The need to overcome human threats from pathogenic microbes, development of nanomaterials have been provoked for a new generation of antimicrobials. In the present study, biosynthesis of silver nanoparticles (AgNPs) was acquired using Comamonas acidovorans extract within $72 \mathrm{~h}$ under static condition. Electron microscopy studies revealed that the size of AgNPs was ranging from $6-53 \mathrm{~nm}$ and had spherical, oval and irregular shapes with smooth surfaces. Prepared AgNPs interacted with proteins, carbohydrates and other aromatic molecules. Biosynthesized AgNPs were bactericidal, which significantly inhibited pathogenic microbes, i.e., Streptococcus pyogenes, Staphylococcus aureus and Escherichia coli. Higher concentrations of AgNPs $\left(20 \mu \mathrm{g} \mathrm{ml}^{-1}\right)$ inhibited 92-98\% growth of all tested bacteria within $24 \mathrm{~h}$. AgNPs-protein network studies carried out to recognize the protein interactions with AgNPs and to understand probable bactericidal mechanisms. AgNPs may penetrate into cell through membrane proteins and damage them by modifying amino acids. Due to AgNPs-protein interactions, dysfunctions in enzymes obstruct certain metabolic processes, which cause the bacteria to die eventually. In
\end{abstract}

Electronic supplementary material The online version of this article (doi:10.1007/s13205-017-0728-3) contains supplementary material, which is available to authorized users.

Darshan M. Rudakiya

darshan.rudakiya@hotmail.com

1 Department of Microbiology, Natubhai V. Patel College of Pure and Applied Sciences, Vallabh Vidyangar, Anand, Gujarat 388 120, India

2 Ashok and Rita Patel Institute of Integrated Study and Research in Biotechnology and Allied Sciences, New Vallabh Vidyanagar, Gujarat 388 121, India certain pathogenic microbes, cue and cus systems detoxify $\mathrm{Ag}^{+}$ions, transport through transporter proteins and expel them to the extracellular space, which are mainly responsible for Ag resistance.

Keywords Bactericidal · Comamonas acidovorans . Computational approach $\cdot$ Nanoparticle-protein interaction $\cdot$ Silver nanoparticles

\section{Introduction}

In 2015, World Health Organization (WHO) published a report on global antimicrobial resistance surveillance system wherein several microbes, i.e., Escherichia coli, Staphylococcus aureus, Shigella sp., Klebsiella pneumoniae and Salmonella sp. are more highlighted due to their resistance towards one or several antibiotics as they are commonly present in communities and hospitals (World Health Organization 2015). As pathogenic microbes evolve certain machineries for resistance of antibiotics, the rate of antibiotic resistance was increased drastically in last decades (Blair et al. 2015). Due to this reason, the development of new antimicrobial agent becomes a challenging task for researchers. To figure out this problem, nano research is more concerned about the development of effective antibacterial agents (Pelgrift and Friedman 2013).

Since antiquity, silver has been used to prevent gonorrhoeal eye infections, to repair vaginal tears after childbirth and to avoid infection of surgical wounds (Lemire et al. 2013; Bhatia et al. 2016). Due to the large surface-area-tovolume ratio, a nano form of silver is catalytically more active than the bulk material. The nano form of silver is greatly noticed due to the high reactivity and broad antimicrobial spectrum with low doses (Rai et al. 2014). In 
addition, silver represents less toxicity towards humans at lower concentrations; thus, it has been widely incorporated with drugs under various forms (salts, immobilized ions or nanoparticles) (Le Ouay and Stellacci 2015). Biosynthesis of nanoparticles is an effective alternate that comprises clean, non-toxic and "green" procedures, while physical and chemical synthesis requires higher energy and toxic chemicals (Mohanpuria et al. 2008; Kharissova et al. 2013). Researchers comprehensively studied the physical, chemical and biological properties of biosynthesized AgNPs and confirmed as an efficient antiviral, antibacterial, antifungal, anticancer and anti-proliferative agent (Lara et al. 2011; Kathiravan et al. 2014; Muniyappan and Nagarajan 2014; Yehia and Al-Sheikh 2014; Abdel-Hafez et al. 2016). Several studies have been accomplished to comprehend the bactericidal mechanisms of AgNPs, which are as follows: (1) AgNPs inhibit the cell membrane and membrane proteins; subsequently, they destroy the cell membrane, (2) AgNPs strongly bind with negatively charged proteins and nucleic acids, (3) AgNPs block respiratory chains by binding with enzymes, and (4) AgNPs generate reactive oxygen species, which lead to the structural and functional changes in the cell (Lara et al. 2010; Rai et al. 2014).

Although the higher bactericidal activity of AgNPs was recorded, less information was obtained regarding AgNPs and its interactions with proteins present in Gram negative and Gram positive bacteria. It is necessary to understand the protein that interacted with AgNPs, interaction types and subsequent pathway that leads to the cell death in bacteria. Several pre-computed databases are available that provide the networks of protein-chemicals interactions (Kuhn et al. 2013) and functional annotations of proteins (Ashburner et al. 2000; Kanehisa and Goto 2000; Caspi et al. 2016). In our study, these databases are useful to understand the interactions between AgNPs and involved functional partners of pathogenic bacteria.

The present study is concentrated to evaluate the physico-chemical properties and bactericidal activity of biosynthesized AgNPs. To the best of our knowledge, this is the first attempt, which represents AgNPs-protein interaction network studies in pathogenic bacteria.

\section{Materials and methods}

\section{Bacterial strains and chemicals}

Comamonas acidovorans (3364) was procured from Microbial Type Culture Collection and Gene Bank, Institute of Microbial Technology (Chandigarh, India). All bacterial strains were maintained and sub-cultured after every week on nutrient agar. Silver nitrate $\left(\mathrm{AgNO}_{3}\right)$ was procured from Sigma-Aldrich Co. (St. Louis, USA). AgarAgar and bacteriological media were purchased from $\mathrm{Hi}$ media Labs (Mumbai, India).

\section{Preparation of AgNPs using cell-free extract}

The culture of $C$. acidovorans was grown in nutrient broth at $30{ }^{\circ} \mathrm{C}$ for $48 \mathrm{~h}$. Cell-free extract was acquired by centrifuging the grown culture at $10,000 \mathrm{rpm}$ and $4{ }^{\circ} \mathrm{C}$ for $15 \mathrm{~min}$ in sterile tubes. Cell-free extract was separately added into a sterile flask containing an equal amount of sterile $\mathrm{AgNO}_{3}(1 \mathrm{mM})$. The reduction $\mathrm{AgNO}_{3}$ was incubated for $72 \mathrm{~h}$ at room temperature under static condition. Additionally, cell-free extract and $\mathrm{AgNO}_{3}$ samples also incubated individually for $72 \mathrm{~h}$ at room temperature to observe color change in the samples. The sample of reaction mixture withdrew after every $12 \mathrm{~h}$, and absorption spectrum of each sample was investigated using UV-Vis spectrophotometer (Shimadzu UV 1800, Japan) in the range of $300-700 \mathrm{~nm}$ at a resolution of $2 \mathrm{~nm}$. AgNPs pellet was recovered by centrifuging $(15,000 \mathrm{rpm})$ it for $20 \mathrm{~min}$ and repetitively washing with distilled water. After, being air dried centrifuged pellet at $40{ }^{\circ} \mathrm{C}$ for $24 \mathrm{~h}$, AgNPs powder proceed for characterization study.

\section{Characterization of AgNPs}

The shape and size of AgNPs were detected under transmission electron microscope. To prepare the AgNPs sample for TEM, copper grid (300 mesh size) was dipped in AgNPs solution and dried in air for $10 \mathrm{~min}$. Further, the sample was proceeded for TEM analysis (Tecnai T20, Philips) at $200.0 \mathrm{keV}$. The surface morphology and size of AgNPs were observed using field emission gun scanning electron microscopy (FEG-SEM) under vacuum $\left(5 \times 10^{-3}\right.$ $\mathrm{Pa})$ at $20.0 \mathrm{kV}$ with $150,000 \times$ magnification. Traces of metals in cell-free extract and AgNPs solution were detected in energy-dispersive X-ray analysis (EDXA) (Nano Nova SEM 450, USA). Crystalline nature of AgNPs powder was detected by X-ray diffractometer (Philips Xpert MPD, Holland). The full widths at half maximum and $2 \theta$ values were used in Debye-Scherrer formula to calculate the average crystalline size of AgNPs. The interaction between functional groups of cell-free extract with AgNPs was analysed using FTIR spectroscopy (Spectrum GX, Perkin Elmer, USA). Dried powder (2 mg) of bacterial extract and AgNPs individually mixed with $\mathrm{KBr}$ crystals $(150 \mathrm{mg})$ and compressed to form pellet which further analysed in mid-infrared light region of $400-4000 \mathrm{~cm}^{-1}$. 


\section{Antibacterial susceptibility assessment}

AgNPs were examined for their effect on Gram-negative and Gram-positive pathogenic microbes using well diffusion and growth curve method. In the well diffusion method, AgNPs solution $\left(10 \mu \mathrm{g} \mathrm{ml}^{-1}\right)$ was compared with $\mathrm{AgNO}_{3}\left(10 \mu \mathrm{g} \mathrm{ml}^{-1}\right)$ and bacterial supernatant against pathogenic bacteria. The zone of inhibition was measured after $24 \mathrm{~h}$ of incubation. In the growth curve method, control and AgNPs solution $\left(5,10,15,20 \mu \mathrm{g} \mathrm{ml}^{-1}\right)$ containing all bacterial culture was incubated for $24 \mathrm{~h}$ to evaluate $\%$ inhibition efficacy.

\section{AgNPs-protein interaction study}

In silico nanoparticle-protein interaction approach was used to understand the possible interaction mechanism. Twelve Gram-negative and six Gram-positive pathogenic bacterial strains were used for interaction study. STITCH 4.0, a pre-computed database resource, offers a proteinchemical interaction network that incorporates many experimental sources and manually curated evidence with text-mining information and predictions (Kuhn et al. 2013). STITCH score is based on gene ontology, which is grouped by $p$-value. The annotations of $p$ value and gene ontology were used to understand the biological process, cellular component and molecular function involved in AgNPs interaction using MetaCyc (Caspi et al. 2016). Along with STITCH 4.0, several databases such as KEGG, Transporter Classification Database and Gene Ontology, provide valuable information regarding functional partners and functional annotations (Kanehisa and Goto 2000; Ashburner et al. 2000; Saier et al. 2006).

\section{Results and discussion}

\section{Synthesis of AgNPs using cell-free extract}

The primary investigation of AgNPs formation was confirmed using visual color change and UV-visible spectroscopy. The color of the reaction mixture gradually altered from pale yellow to dark brown that confirmed the formation of AgNPs after $72 \mathrm{~h}$ of incubation. Figure 1 represents the sharp surface plasma resonance peak that evolved at $450 \mathrm{~nm}$ after $24 \mathrm{~h}$ of incubation. It is a representative characteristic of AgNPs formation. A broad and strong surface plasma resonance peak was observed between 445 to $455 \mathrm{~nm}$ after $72 \mathrm{~h}$ of incubation. There was no color alteration and absorbance peak observation at $450 \mathrm{~nm}$ in the individual solution of cell-free extract and $\mathrm{AgNO}_{3}$ after $72 \mathrm{~h}$ of incubation. Similar results were observed by Jeevan et al. (2012) when AgNPs were

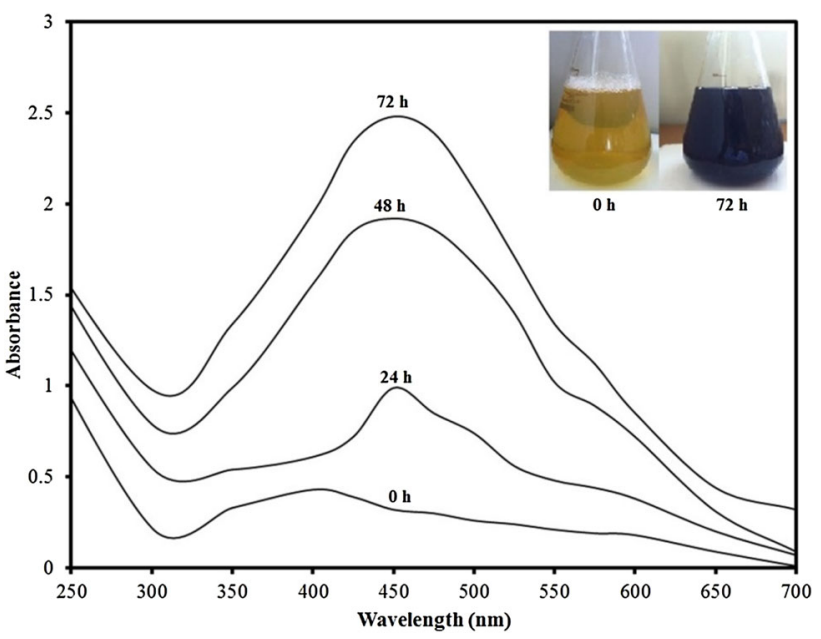

Fig. 1 UV-visible spectrum of the AgNPs represented the maximum absorbance peak observed at $450 \mathrm{~nm}$ after $72 \mathrm{~h}$ and color of bacterial supernatant changed from light yellow to dark brown (inset)

synthesized using the supernatant of $P$. aeruginosa culture for $72 \mathrm{~h}$ under bright condition. Incubation of $\mathrm{AgNO}_{3}$ with M. dubia leaf extract showed the major absorbance peak at $448 \mathrm{~nm}$ that confirmed the formation of AgNPs (Kathiravan et al. 2014).

\section{Characterization of AgNPs}

The preparation of AgNPs is further confirmed using microscopic, spectroscopic and diffractometric analysis. TEM micrographs display the different size and shape of AgNPs at 50 and $100 \mathrm{~nm}$ scale as shown in Fig. 2. The sample of nanoparticles exhibited a difference in their size from 6 to $53 \mathrm{~nm}$. The majority of nanoparticles are spherical, while others are oval-shaped (Fig. 2b, inset). Irregular and larger sized nanoparticles are also visualized in Fig. 2a. Size of spherical and oval-shaped nanoparticles was ranging from 6 to $30 \mathrm{~nm}$, while irregular-shaped particles were comparatively larger $(30-52 \mathrm{~nm})$. The selectedarea electron diffraction (SAED) pattern of AgNPs detected the plane of nanoparticles (Fig. 2a, inset). The AgNPs were magnified up to $150,000 \times$ to observe the surface area and shape of nanoparticles under FEG-SEM. These nanoparticles, ranging from 7 to $50 \mathrm{~nm}$, were visualized with oval, spherical and irregular shapes (Fig. 3a).

FEG-SEM and TEM measurements are frequently used to determine the shape, size and morphology of the nanoparticles. In the present study, these techniques confirmed that the prepared nanoparticles had smooth surface edges but they were in different shapes. Less-homogenized spherical AgNPs were synthesized by culture supernatant of S. hygroscopicus (Sadhasivam et al. 2010). The extract of B. amyloliquefaciens was used to synthesize AgNPs, which were spherical and triangular shaped (Wei et al. 

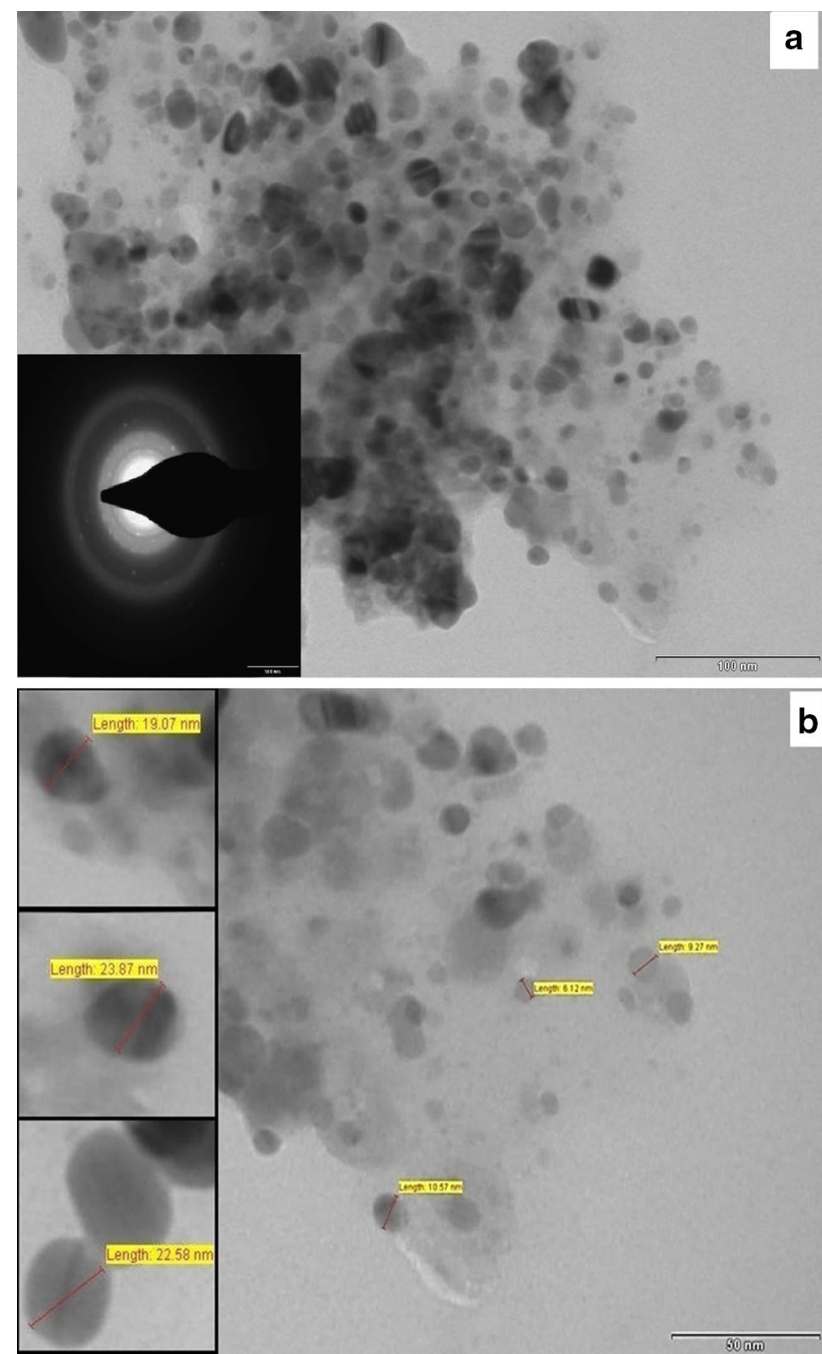

Fig. 2 TEM micrographs of AgNPs at 100-nm (a) and 50-nm scale (b), enlarged view of oval- and spherical-shaped AgNPs (b; inset) and SAED pattern of biosynthesized nanoparticles $(\mathbf{a}$; inset $)$

2012). Different shapes of nanoparticles such as spherical, oval, triangular and irregular observed when they prepared using biological methods. Sedimentation has been occurring in the late stages of AgNPs formation; so, nanoparticles were agglomerated. This might be the possible reason for the synthesis of large nano-spherical nanoparticles (Ahmad et al. 2013).

The appearance of silver in EDAX spectrum confirmed the presence of Ag metal in AgNPs solution as shown in Fig. 3a (inset). Weight (\%) of major element signals of $\mathrm{C}$ (63.96), $\mathrm{O}(5.83)$, and $\mathrm{Na}(0.21)$ was detected in the cellfree extract. The presence of these elements was expected, as they were the major components of bacterial extract. Weights (\%) of $\mathrm{Ag}$ (21.25), $\mathrm{O}$ (49.59), $\mathrm{Na}$ (28.24), and $P$ (0.93) were observed in AgNPs powder. The optical absorption peak observed at $3 \mathrm{kV}$ is the representative peak of pure metallic silver nanoparticles due to surface plasma resonance (Jain et al. 2011). Stoichiometric study revealed the higher relative content of $\mathrm{Ag}^{+}$ions present in AgNPs powder. The XRD pattern revealed the crystalline nature of AgNPs using the peaks at $2 \theta$ value of $32.31,38.54,45.80$, and 46.97. The size of AgNPs at different position is 26.60, $32.59,51.10$ and $52.00 \mathrm{~nm}$. The average crystalline size of AgNPs calculated using Debye-Scherrer's equation is $40.57 \mathrm{~nm}$. Several researchers studied the average size of AgNPs synthesized using culture supernatant of $P$. aeruginosa were 50-80 nm. An average size of AgNPs prepared in the present study is $40 \mathrm{~nm}$, which is lower than the previous studies (Jeevan et al. 2012; Jeyaraj et al. 2013).

FTIR measurements were carried out to identify the functional groups involved in the AgNPs reduction (Fig. 3b). Characteristics of FTIR spectra and the shift changes in AgNPs powder is presented in Table 1. The peaks near $3437 \mathrm{~cm}^{-1}$ are attributed to $\mathrm{N}-\mathrm{H}$ stretching vibrations of a peptide linkage in bacterial extract and AgNPs powder (Kumar and Mamidyala 2011). Bacterial extract and AgNPs powder showed the prominent peak of asymmetrical and symmetrical $\mathrm{C}-\mathrm{H}$ stretching vibrations $\left(\mathrm{CH}_{3}\right)$ of carbohydrates and fatty acids at 2930 and $2926 \mathrm{~cm}^{-1}$. The other peaks of carbohydrates and fatty acids were observed at $2856 \mathrm{~cm}^{-1}$ supporting the weak C$\mathrm{H}$ stretching vibrations of aldehyde group. The interaction of the proteins with AgNPs was confirmed by the presence of peaks of carbonyl groups $(\mathrm{C}=\mathrm{O})$ and $\mathrm{C}-\mathrm{N}$ plane vibrations of amines at 1645 and $1639 \mathrm{~cm}^{-1}$ (Jeevan et al. 2012). There are two bands at 1639 and $1544 \mathrm{~cm}^{-1}$ that corresponded to amide I and II bonds of proteins, respectively (Jain et al. 2011). The peaks at 1456 and $1458 \mathrm{~cm}^{-1}$ corresponded to $\mathrm{C}-\mathrm{H}$ deformation of aliphatic compounds present in carbohydrates and fatty acids. The peaks at 1401 and $1403 \mathrm{~cm}^{-1}$ were assigned to the geminal methyls (Vidhu and Philip 2014). A C-N stretching vibration of primary aliphatic amines evolved at $1119 \mathrm{~cm}^{-1}$ by interacting with $\mathrm{Ag}^{+}$ions.

The peak of $\mathrm{R}-\mathrm{CO}-\mathrm{NH}_{2}$ stretching vibrations near $1080 \mathrm{~cm}^{-1}$ revealed the presence of proteins in bacterial extract and AgNPs powder (Jain et al. 2011). A peak of $\mathrm{CH}=\mathrm{CH}_{2}$ bond of vinyl compounds evolved at $931 \mathrm{~cm}^{-1}$ by interacting with $\mathrm{Ag}^{+}$ions. The peak for methylene rocking vibration and out-of-plane $\mathrm{C}-\mathrm{H}$ bending vibration in mononuclear hydrocarbon was assigned at $712 \mathrm{~cm}^{-1}$ that displayed in the bacterial extract. The peaks for $\mathrm{C}-$ $\mathrm{O}-\mathrm{C}$ and $\mathrm{P}-\mathrm{O}-\mathrm{C}$ groups in phospholipids, aromatics, amino acids (rocking vibrations) and ketones are assigned at 554 and $536 \mathrm{~cm}^{-1}$. An alteration in these peaks $\left(+17.93 \mathrm{~cm}^{-1}\right)$ suggested the strong interaction of aromatics, lipids, amino acids as well as ketones. FTIR study revealed the presence and binding of protein, carbohydrates and aromatics and fatty acids with AgNPs. It is well known that the proteins bind with nanoparticles 
Fig. 3 High-resolution FEGSEM images of AgNPs at $\times 150,000$ magnification $(\mathbf{a})$, the presence of $\mathrm{Ag}$ metal confirmed by EDAX analysis (a, inset) and FTIR images of bacterial supernatant and AgNPs (b)
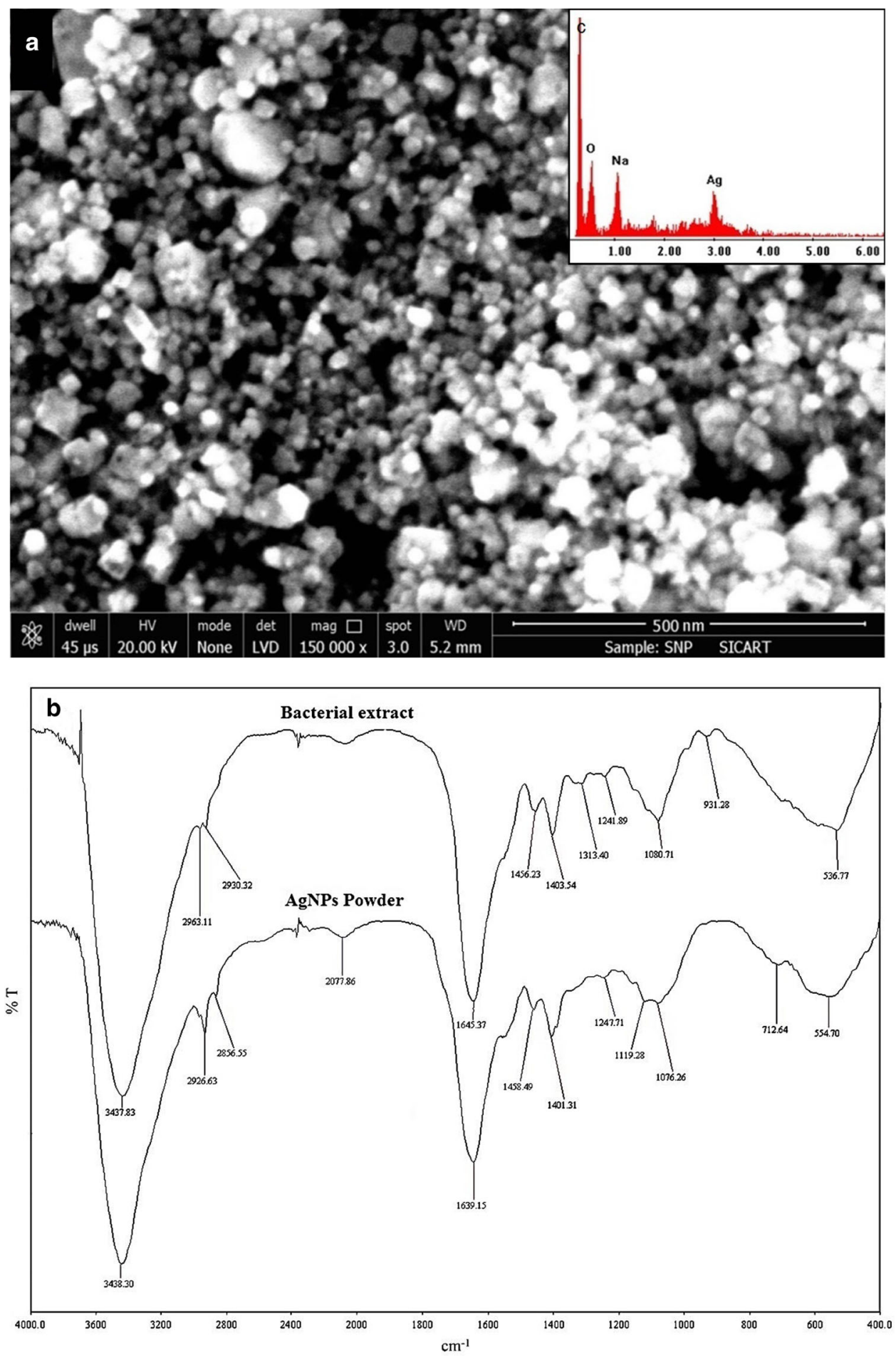

through cysteine residues or free amino groups (Jeevan et al. 2012). Electrostatic interactions of negatively charged carboxyl groups in proteins also bind with nanoparticles. These biological components may play a significant role in the formation and stabilization of nanoparticles (Wei et al. 2012; Ahmad et al. 2013).

\section{Antibacterial susceptibility assessment}

Bactericidal activities of biosynthesized AgNPs revealed that the inhibition was comparatively higher than $\mathrm{AgNO}_{3}$. It inhibited Gram-positive and Gram-negative bacteria very efficiently (Table 2). The inhibition zone of AgNPs 
Table 1 Fourier-transform infrared spectral characteristics of bacterial extract and AgNPs powder

\begin{tabular}{|c|c|c|c|c|c|}
\hline \multirow[t]{2}{*}{ No. } & \multirow[t]{2}{*}{ Description } & \multicolumn{2}{|c|}{ Wavenumber $\left(\mathrm{cm}^{-1}\right)$} & \multirow[t]{2}{*}{ Difference $^{\mathrm{a}}$} & \multirow[t]{2}{*}{ Possible reason for the shift alteration } \\
\hline & & $\begin{array}{l}\text { Bacterial } \\
\text { extract }\end{array}$ & $\begin{array}{l}\text { AgNPs } \\
\text { powder }\end{array}$ & & \\
\hline 1 & $\mathrm{~N}-\mathrm{H}$ stretching vibrations of peptide linkage & 3437.83 & 3438.30 & +0.47 & Interaction with proteins \\
\hline 2 & $\begin{array}{l}\text { Asym and sym } \mathrm{C}-\mathrm{H} \text { stretching vibration of } \\
\text { aliphatics }\end{array}$ & $\begin{array}{l}2930.32 \\
2963.11\end{array}$ & 2926.63 & -3.69 & $\begin{array}{l}\text { Interaction with fatty acids and } \\
\text { carbohydrates }\end{array}$ \\
\hline 3 & $\begin{array}{l}\text { Carbonyl group }(\mathrm{C}=\mathrm{O}) \text {, amide I group stretching } \\
\text { vibrations }\end{array}$ & 1645.37 & 1639.15 & -6.22 & Binding with proteins \\
\hline 4 & Amide II group stretching vibrations & 1547.55 & 1544.91 & -2.64 & Interaction with proteins \\
\hline 5 & $\mathrm{C}-\mathrm{H}$ deformation of $\mathrm{CH}_{2}$ or $\mathrm{CH}_{3}$ in aliphatics & 1456.23 & 1458.49 & +2.26 & $\begin{array}{l}\text { Interaction with fatty acids and } \\
\text { carbohydrates }\end{array}$ \\
\hline 6 & Geminal methyls & 1403.54 & 1401.31 & -2.23 & Interaction with methyls \\
\hline 7 & Amide III group stretching vibrations & 1241.89 & 1247.71 & 5.82 & Interaction with proteins \\
\hline 8 & $\begin{array}{l}\mathrm{C}-\mathrm{N} \text { stretching vibrations of primary aliphatic } \\
\text { amines }\end{array}$ & - & 1119.28 & - & Interaction with proteins \\
\hline 9 & $\begin{array}{l}\mathrm{P}=\mathrm{O} \text { stretching in phospholipids and } \mathrm{C}=\mathrm{O} \text { group in } \\
\text { polysaccharides }\end{array}$ & 1080.71 & 1076.26 & -4.45 & Interactions with lipids and carbohydrates \\
\hline 10 & $\mathrm{C}-\mathrm{O}-\mathrm{C}$ and $\mathrm{P}-\mathrm{O}-\mathrm{C}$ bond stretching & 536.77 & 554.70 & +17.93 & $\begin{array}{l}\text { Strong interactions of phospholipids, } \\
\text { aromatics and sugars }\end{array}$ \\
\hline
\end{tabular}

Asym asymmetrical, sym symmetrical

${ }^{\text {a }}$ Shift difference: shift increase + , shift decrease -

Table 2 Antibacterial activity of $\operatorname{AgNPs}\left(10 \mu \mathrm{g} \mathrm{ml}^{-1}\right)$ and $\mathrm{AgNO}_{3}$ against pathogenic bacteria

\begin{tabular}{|c|c|c|c|c|c|}
\hline \multirow[t]{2}{*}{ Gram-negative bacteria } & \multicolumn{2}{|c|}{ Zone of inhibition (mm) } & \multirow[t]{2}{*}{ Gram-positive bacteria } & \multicolumn{2}{|c|}{ Zone of inhibition (mm) } \\
\hline & AGNPs & $\mathrm{AgNO}_{3}$ & & AGNPs & $\mathrm{AgNO}_{3}$ \\
\hline Escherichia coli & 22.0 & 14.0 & Streptococcus pyogenes & 17.5 & 12.4 \\
\hline Psuedomonas aeruginosa & 16.7 & 11.2 & Staphylococcus aureus & 17.2 & 11.9 \\
\hline Salmonella typhi & 15.7 & 10.5 & Bacillus subtilis & 15.0 & 10.8 \\
\hline
\end{tabular}

was higher in the case of E. coli $(22 \mathrm{~mm})$ and $S$. pyogenes $(17.5 \mathrm{~mm})$. AgNPs also inhibited other bacteria, such as $S$. aureus $(17.2 \mathrm{~mm}), P$. aeruginosa $(16.7 \mathrm{~mm})$, S. typhi $(15.7 \mathrm{~mm})$ and B. subtilis $(15.0 \mathrm{~mm})$. Bacterial extract and distilled water were taken as negative controls which did not obtain inhibition zone. The inhibition zone of AgNPs synthesized using $S$. hygroscopicus observed in case of E. coli and B. subtilis was lower than the present study (Sadhasivam et al. 2010). AgNPs-layered double hydroxide also displayed the similar inhibition efficacy in the case of $S$. aureus and E. coli (Mishra et al. 2013). Similarly, mean diameters of inhibition zone for AgNPs (average TEM size; $30 \mathrm{~nm}$ ) against E. coli and $S$. aureus were 24 and $19 \mathrm{~nm}$, respectively (Ahmad et al. 2013).

The inhibition profile against pathogenic bacteria was remarkably detected in liquid condition than on agar medium. E. coli, S. aureus and P. aeruginosa were inhibited at $\quad 60.39 \pm 1.19, \quad 51.49 \pm 1.27 \quad$ and $49.61 \pm 1.02 \%$, respectively, after $24 \mathrm{~h}$ at even $5 \mu \mathrm{g} \mathrm{ml}$ concentration of AgNPs. All tested Gram-negative and Gram-positive bacteria were highly susceptible to AgNPs at $20 \mu \mathrm{g} \mathrm{ml}^{-1}$ concentration within $24 \mathrm{~h}$ of incubation. The synthesized AgNPs highly decreased the growth of pathogenic bacteria, i.e. E. coli $(98.08 \pm 1.11 \%), P$. aeruginosa (94.55 $\pm 0.99 \%)$, S. typhi (88.49 $\pm 1.34 \%), S$. pyogenes $(96.66 \pm 1.23 \%), S$. aureus $(86.48 \pm 1.10 \%)$, and B. subtilis $(90.38 \pm 1.54 \%)$ within $24 \mathrm{~h}$ (Fig. 4$)$. The growth of all bacteria increased marginally after 24-30 h of incubation even in the presence of AgNPs at concentrations of $5-15 \mu \mathrm{g} \mathrm{ml}^{-1}$. Similar results were observed by Shivaji et al. (2011), when higher concentrations (10 and $20 \mu \mathrm{g} \mathrm{ml}^{-1}$ ) of AgNPs completely inhibited Gram positive and negative bacteria within $20 \mathrm{~h}$. The inhibitory action of prepared AgNPs was effective against $S$. aureus after $24 \mathrm{~h}$ than the study carried out by Li et al. (2011). 

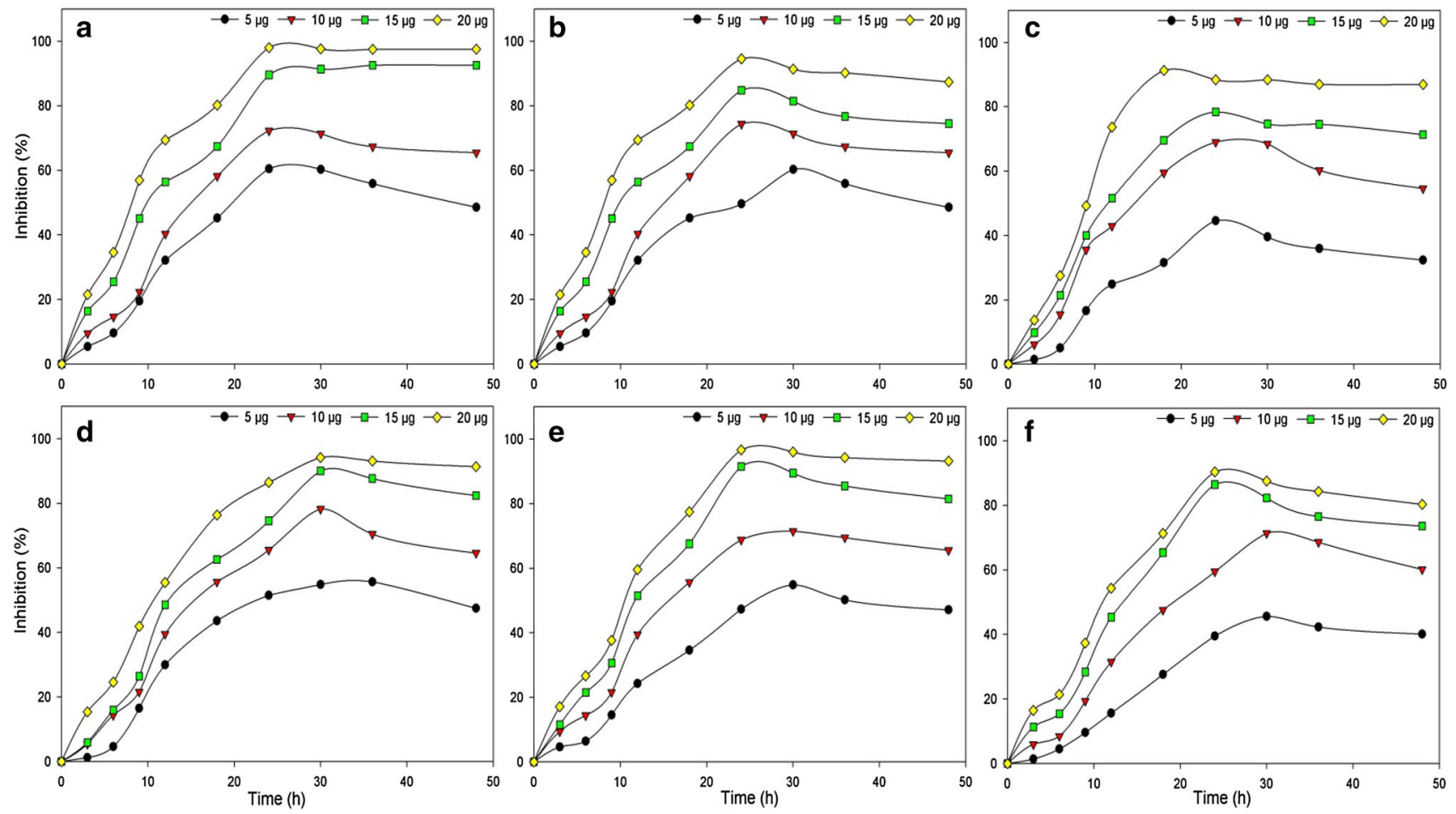

Fig. 4 Bactericidal activity of AgNPs evaluated using growth curve method against six bacteria, i.e., Escherichia coli (a), Pseudomonas aeruginosa (b), Salmonella typhi (c), Staphylococcus aureus (d),

Streptococcus pyogenes (e), and Bacillus subtilis (f) at 5-20 $\mu \mathrm{g} \mathrm{ml}^{-1}$ concentration

\section{AgNPs-protein interaction study}

To understand the involvement of functional partners with AgNPs, STITCH 4.0 tool and Gene Ontology provide a better understanding about the confidence score, biological process and molecular functions of proteins (Table 3 and Table 4; Electronic supplementary material). In all pathogenic bacteria, AgNPs bind with the membranous, cytoplasmic and cell periphery proteins. Figures 5 and 6 represent the AgNPs-protein interaction networks of Gram-negative and Gram-positive bacteria, respectively. The confidence score of these functional partners is more than 0.4 .

In case of E. coli, all functional partners share the highest confidence score (0.9-1.0). The cus and cue systems respond to copper $(\mathrm{Cu})$ stress by oxidizing and/or expelling $\mathrm{Cu}^{+}$ions from the cell. $\mathrm{Ag}^{+}$ion, a mimic of $\mathrm{Cu}^{+}$ ion, acts on the cus as well as cue systems (Singh et al. 2011). CusA, CusB, CusC and CusF are membrane proteins and major components of $\mathrm{Ag} / \mathrm{Cu}$ efflux system, which may be responsible for $\mathrm{Ag}$ resistance in the cell. All functional partners are involved in binding and catalysis of $\mathrm{Ag}^{+}$ions and also transport $\mathrm{Ag}^{+}$ions [GO:0010272], which results the expel $\mathrm{Ag}^{+}$ions from the cell. $\mathrm{CueO}$ (multi-copper oxidase) is regulated by CueR (DNA binding transcriptional activator of $\mathrm{Cu}$-responsive regulon genes) and responsible to decrease stress levels of $\mathrm{Ag}$. CueO enzyme binds and transports $\mathrm{Ag}^{+}$ions through methioninerich motifs (Singh et al. 2011). The $p$ values for the GO terms of these proteins are statistically significant ( $p$ value $\leq 0.05$ ) as obtained from STRING database. $\mathrm{Ag}^{+}$ions also inhibit different enzymes such as fumA, glgP, dcyD and tdh, which are involved in citric acid cycle [GO:0006099], starch and sucrose catabolism [GO:0005977], cysteine catabolism [GO:0019447], and threonine catabolism [GO:0006567]. The amino acids, carbohydrates as well as routine metabolic pathways disturb due to the binding of $\mathrm{Ag}^{+}$ions obstruct the enzyme activities. Experimental data presented by $\mathrm{Li}$ et al. (2010) revealed that the dehydrogenase activities of $E$. coli were rapidly decreased after incubating with AgNPs.

Alcohol dehydrogenase (PA4097) and oxidoreductase (PA1648) were inhibited because of interacting $\mathrm{Ag}^{+}$ions in $P$. aeruginosa PAO1. Inhibition of certain cytoplasmic enzymes may lead to discontinue cellular processes, i.e., glycolysis, fatty acid degradation, amino acid metabolism, secondary metabolite synthesis, etc. Metal-ion-transporting ATPases (PA1549, PA3920), cation efflux transporter (czcA) and metallo-oxidative reductase (PA3768) bind with AgNPs, which are responsible for cation transporter activity [GO:0006812] and oxidoreductase activity [GO:0016491]. Kora and Arunachalam (2011) showed the 

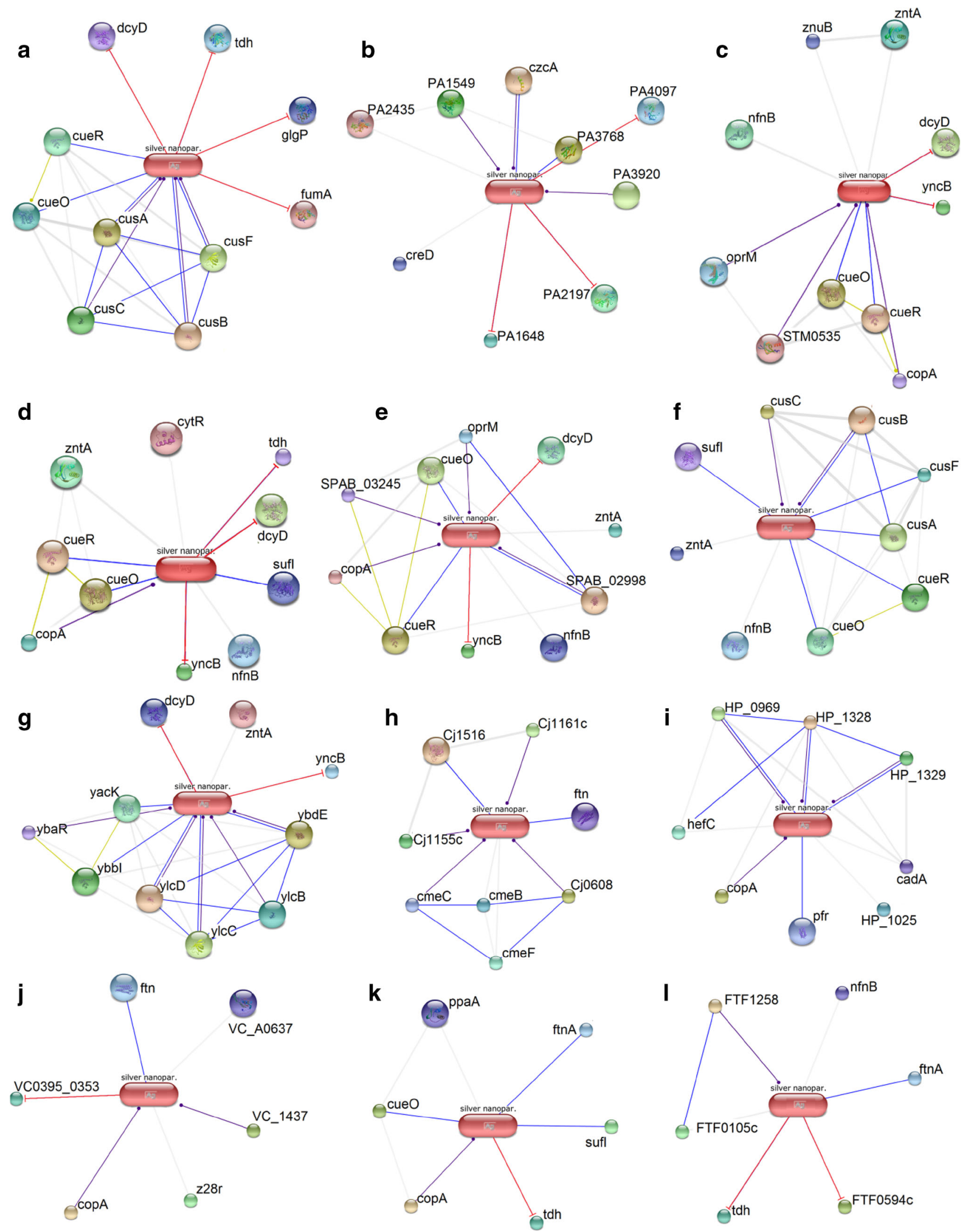
4Fig. 5 AgNPs-protein interaction networks of 12 Gram-negative pathogenic bacteria such as Escherichia coli (a), Pseudomonas aeruginosa (b), Salmonella typhimurium (c), Salmonella typhi (d), Salmonella enterica (e), Klebsiella pneumoniae (f), Shigella sonnei (g), Campylobacter jejuni (h), Helicobacter pylori (i), Vibrio cholerae (j), Proteus mirabilis (k) and Francisella tularensis (l). An individual line between protein and AgNPs represents an interaction node wherein blue line for binding, purple line for catalysis, light green line for expression and red line for inhibition

involvement of reactive oxygen species in $P$. aeruginosa that may generate from the surface of AgNPs and damage cell membrane and membrane proteins.

The functional partners and interaction networks of $S$. typhimurium, $S$. typhi, and $S$. enterica are similar that interact with AgNPs. $\mathrm{Ag}^{+}$ions bind with dcyD, tdh and yncB (NADP-dependent oxidoreductase) enzymes and obstruct the activities in the cytoplasm. yncB possesses the oxidoreductase activity [GO:0055114] in the cytoplasm. $\mathrm{Ag}^{+}$ions bind with cueO enzyme, which transports $\mathrm{Ag}^{+}$ ions through methionine-rich motifs (Singh et al. 2011). $\mathrm{Ag}^{+}$ion-transporting process [GO:0019829] is acted by copA in Salmonella sp. Interaction networks and functional partners of $K$. pneumoniae 342 and E. coli display higher similarity. Alike E. coli, K. pneumoniae 342 has cus and cue system, which detoxifies and expels $\mathrm{Ag}^{+}$ions to extracellular space.

Majority of the functional partners present in H. pylori G27 are membranous proteins and enzymes that catalyze $\mathrm{Ag}^{+}$ions and play important role in $\mathrm{Ag}$ resistance. HP_1328, HP_0969, and HP_1329, are membranous proteins and part of the cation efflux system. The efflux protein system is also involved in the resistance of certain metal ions, i.e. $\mathrm{Ag}, \mathrm{Co}, \mathrm{Zn}$ and $\mathrm{Cd}$. Gurunathan et al. (2015) showed the possible bactericidal mechanism of AgNPs in H. pylori wherein increase in reactive oxygen species (ROS), DNA fragmentation, membrane leakage and mitochondria-mediated apoptosis were observed $(\mathrm{Gu}-$ runathan et al. 2015). Alike H. pylori G27, the functional partners of $C$. jejuni 11168 are present in membrane. Cj0608 (efflux protein) is present in outer membrane; $\mathrm{Cj} 1516$ (periplasmic oxidoreductase) is present in periplasmic space of membrane; and Cj1161c (ATPase), $\mathrm{Cj} 1155 \mathrm{c}$ (ATPase) and $\mathrm{cmeC}$ (multidrug resistance cme $A B C$ protein) are present in inner side of the membrane. All proteins are involved in $\mathrm{Ag}$ resistance in $C$. jejuni 11168. In case of $S$. sonnei, yncB and dcyD are inhibited by $\mathrm{Ag}^{+}$ions, which obstructed oxidoreductase processes and cysteine catabolism. The ylcD, ylcB and

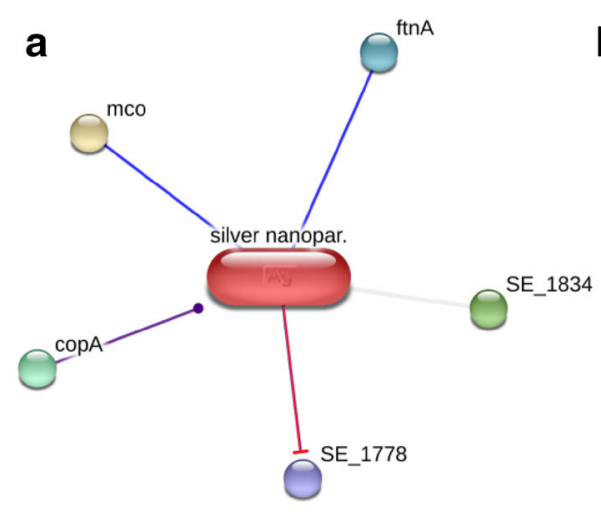

b
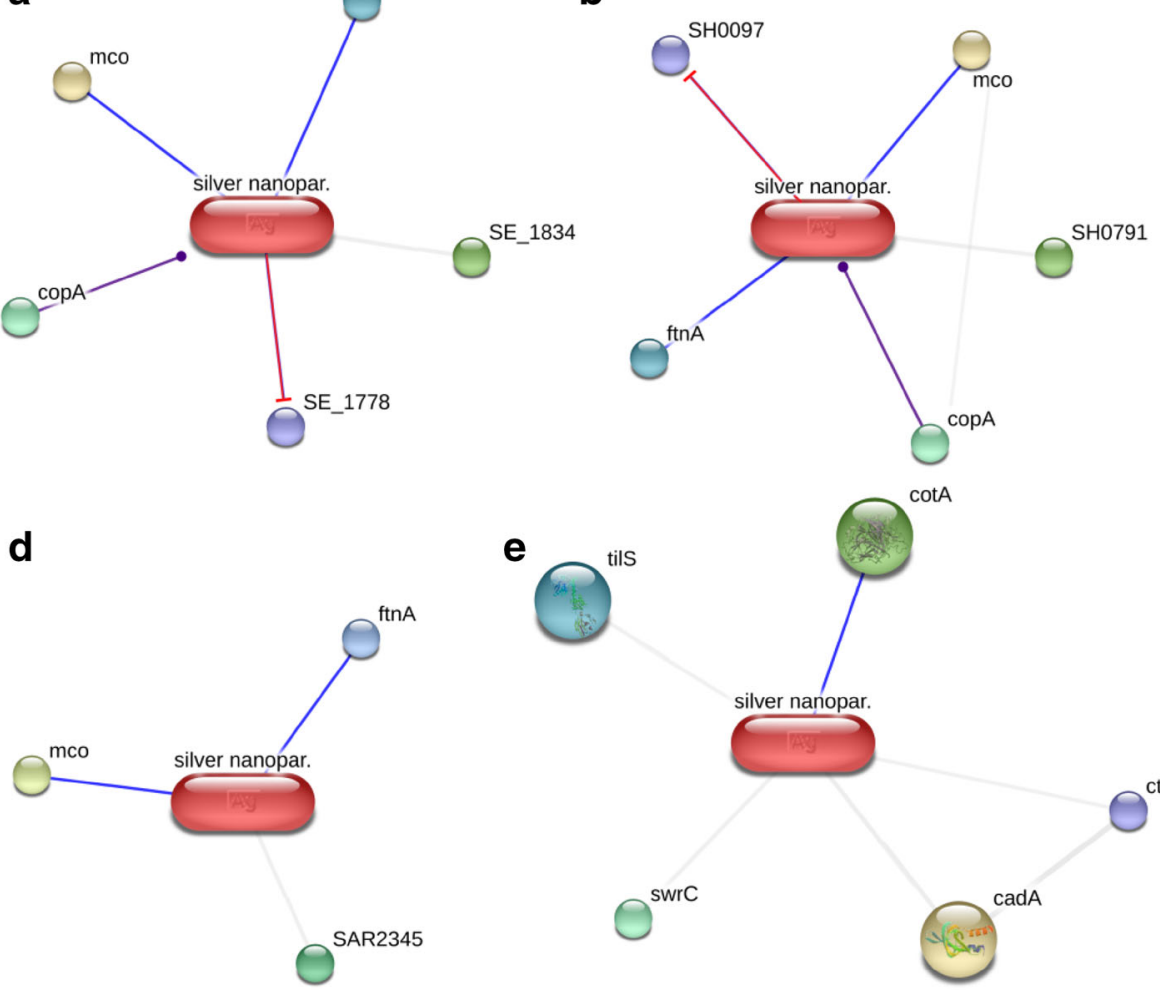

Fig. 6 AgNPs-protein interaction networks of six Gram-positive pathogenic bacterial strains like Staphylococcus epidermidis (a), Staphylococcus haemolyticus (b), Staphylococcus saprophyticus (c), Staphylococcus aureus (d), Bacillus subtilis (e) and Streptococcus
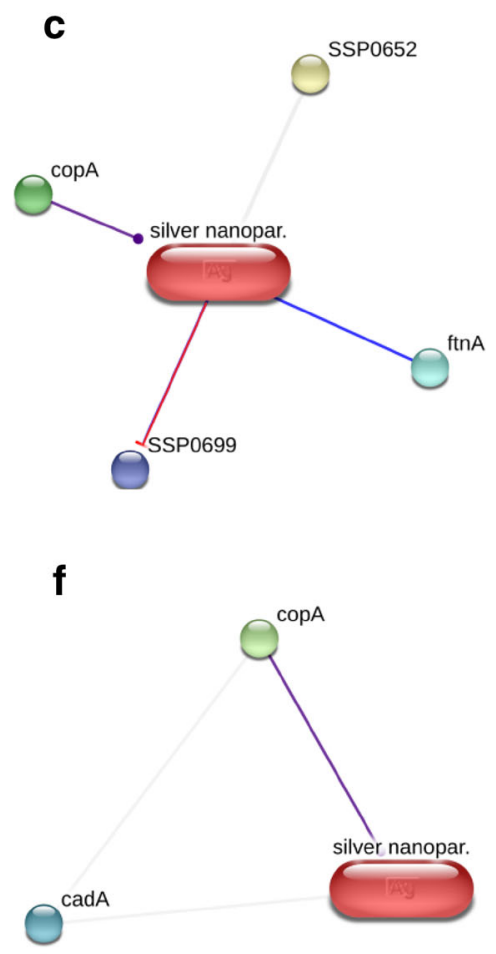

pyogenes (f). An individual line between protein and AgNPs represents an interaction node wherein blue line for binding, purple line for catalysis and interaction block represented as red line, which shows inhibition 
ylcC $(\mathrm{Cu} / \mathrm{Ag}$ efflux system protein) detoxify and transport $\mathrm{Ag}^{+}$ions to extracellular space. $\mathrm{Ag}^{+}$ions also inhibit the transcription regulator (ybbI) and stop the transcription activity in $S$. sonnei.

In case of $F$. tularensis FSC198, outer membrane efflux protein (FTF1258) could absorb and expel $\mathrm{Ag}^{+}$ions into extracellular space. Similar to E. coli, $\mathrm{Ag}^{+}$ions inhibit tdh (threonine 3-dehydrogenase) and obstruct threonine catabolism [GO:0006567]. Binding to ftnA (ferritin family protein) with $\mathrm{Ag}^{+}$ions may result the interruption in iron homeostasis [GO:0006879]. P. mirabilis shows similar network interactions as tdh and $\mathrm{ftnA}$ are inhibited by binding with $\mathrm{Ag}^{+}$ions. The copA (Cu-transporting P-type ATPase) may act $\mathrm{Ag}^{+}$ion-transporting activity [GO:0019829], while cueO may be involved in detoxification of $\mathrm{Ag}^{+}$ions [GO:0010273]. In V. cholerae O395, VC_1437 and copA are cation-transporting E1-E2 family ATPases that catalyze $\mathrm{Ag}^{+}$ions and show metal-iontransporting ATPase activity [GO:0019829]. VC0395_0353 (threonine 3-dehydrogenase) and ftnA are inhibited by binding with $\mathrm{Ag}^{+}$ions.

S. epidermidis 12228 , S. haemolyticus, S. saprophyticus, and $S$. aureus MRSA252 share similar interaction networks with AgNPs. Quinone oxidoreductase (SE_1778), RND superfamily resistance-nodulation-cell division acriflavin: Proton $\mathrm{H}^{+}$antiporter (SH0097) and NADP-dependent oxidoreductase (SSP0699) inhibit due to the presence of $\mathrm{Ag}^{+}$ ions in the cytoplasm. Based on $p$ value $(\leq 0.05), \mathrm{SE}_{-} 1778$ and SSP0699 exhibit oxidoreductase activity [GO:0016491] as well as SH0097 shares transmembrane transporter activity [GO:0015450]. Multi-copper oxidase (mco) in Staphylococcus sp. acts as oxidation-reduction process [GO:0016491] which is similar to $\mathrm{CueO}$ present in Gram-negative bacteria. Binding of mco with $\mathrm{Ag}^{+}$ions may result into the transportation and detoxification of $\mathrm{Ag}^{+}$ions. copA catalyzes $\mathrm{Ag}^{+}$ions into the cytoplasm, which results in cation-transporting ATPase activity [GO:0019829] and expelling of $\mathrm{Ag}^{+}$ions from cytoplasm to the extracellular space. $\mathrm{Ag}^{+}$ions interrupt iron homeostasis [GO:0006879] by binding with ftnA. Gordon et al. (2010) revealed that the enzymes present in the respiratory chain, glycolysis, citric acid cycle and iron homeostasis interrupted by incubating silver coordination polymers with Staphylococci. Grigor'eva et al. (2013) showed the accumulation of AgNPs into periplasmic space and the lysis of cytoplasm observed which result in the death of $S$. aureus.

In B. subtilis, $\mathrm{Ag}^{+}$ions bind with $\cot \mathrm{A}$ (Spore $\mathrm{Cu}$-dependent laccase), which is mainly responsible for oxidoreductase activity [GO:0016491] and cell differentiation process [GO:0030435]. Binding of $\cot \mathrm{A}$ with $\mathrm{Ag}^{+}$ions may result into transportation and detoxification of $\mathrm{Ag}^{+}$ ions or it may hinder the process of cell differentiation. The copA is only a probable binding interaction observed in $S$. pyogenes. This enzyme is responsible for $\mathrm{Cu} / \mathrm{Ag}$ tolerance in both aerobic and anaerobic conditions which mainly transport $\mathrm{Ag}^{+}$ions [GO:1902601], response to $\mathrm{Ag}^{+}$ions [GO:0071292] and detoxification of $\mathrm{Ag}^{+}$ions [GO:0010273]. Overall, the interaction networks presented in Gram negative bacteria are higher than Gram positive bacteria. Less predicted interaction is observed due to the lack of exact inhibition mechanism in Gram positive bacteria.

Previously, researchers studied the bactericidal mechanisms of AgNPs using certain microscopy and spectroscopy techniques. In addition, several studies have attempted to understand the inhibition of cytoplasmic, membranous and extracellular enzymes in specific bacterial strains (Sadhasivam et al. 2010; Li et al. 2011; Singh et al. 2011). The AgNPs-protein interaction approach gives us better understanding regarding the proteins involved in bactericidal mechanism. Due to this approach, we can compare the functional partners present in pathogenic bacteria and also extract the significant information.

As a whole, adaptation and/or resistance mechanisms of AgNPs are observed in several bacterial strains. The expression and regulation of certain proteins, i.e. metaluptake proteins, efflux proteins, and membrane transporters may cause Ag resistance in bacteria (Lemire et al. 2013). Cus and cue protein systems are actively involved functional partners that are present in most pathogenic bacterial strains (Singh et al. 2011). Though certain Ag resistance systems are observed in bacterial strains, AgNPs work effectively as well as in a systematic manner. Anchoring ability of AgNPs with bacterial cell wall leads to the penetration into cell via transporters and/or co-transport with low-molecular-weight ligands (Rai et al. 2009). After entering into cells, it is supposed that there can be release of $\mathrm{Ag}^{+}$ions from AgNPs, which are more active and unstable in the cell. $\mathrm{Ag}^{+}$ions can lead to the production of reactive oxygen species (Kora and Arunachalam 2011). They interact with thiol groups of proteins and enzymes that caused the enzyme dysfunction. Certain metal ion ligand, i.e. $\mathrm{Cu}^{+}$ion present in copA may be replaced by $\mathrm{Ag}^{+}$ion, which can lead to the dysfunction of the enzyme (Lemire et al. 2013). Several studies suggested that $\mathrm{Ag}^{+}$ ions also interacted with DNA, which caused the fragmentation of DNA (Gurunathan et al. 2015). Eventually, AgNPs react with multiple enzymes, transporter proteins as well as nucleic acids that lead to the cell death.

\section{Conclusion}

Overall, an easy, biological and non-toxic method applied for the preparation of AgNPs using C. acidovorans culture. Even though the prepared AgNPs were small in size and of 
different shapes, reduction time for preparation was limited to $72 \mathrm{~h}$. Proteins, sugars and other molecules are interacted with AgNPs that might stabilize $\mathrm{Ag}^{+}$ions. The biosynthesized AgNPs were an efficient bactericidal agent against pathogenic bacteria. Predicted nanoparticles interactions revealed the possible binding of AgNPs with regulators, enzymes and transporter molecules. AgNPs-protein interaction study suggests that AgNPs may damage the cell membrane, pass through certain membrane proteins and transporters and inhibit the activity of cytoplasmic and membranous enzymes, which cause pathogenic bacteria to die in due course.

Acknowledgements The authors acknowledge SICART, Vallabh Vidyanagar, Anand, for providing the infrastructure, laboratory, instrumental and other necessary facilities for the successful completion of this work.

\section{Compliance with ethical standards}

Funding This research did not receive any specific grant from funding agencies in the public, commercial, or not-for-profit sectors.

Conflict of interest Authors do not declare any conflict of interest.

\section{References}

Abdel-Hafez SI, Nafady NA, Abdel-Rahim IR, Shaltout AM, Daròs JA, Mohamed MA (2016) Assessment of protein silver nanoparticles toxicity against pathogenic Alternaria solani. 3. Biotech 6:199

Ahmad T, Wani IA, Manzoor N, Ahmed J, Asiri AM (2013) Biosynthesis, structural characterization and antimicrobial activity of gold and silver nanoparticles. Colloid Surf B 107:227-234

Ashburner M, Ball CA, Blake JA et al (2000) Gene ontology: tool for the unification of biology. Nature Genet 25:25-29

Bhatia D, Mittal A, Malik DK (2016) Antimicrobial activity of PVP coated silver nanoparticles synthesized by Lysinibacillus varians. 3. Biotech 6:196

Blair JM, Webber MA, Baylay AJ, Ogbolu DO, Piddock LJ (2015) Molecular mechanisms of antibiotic resistance. Nat Rev Microbiol 13:42-51. doi:10.1038/nrmicro3380

Caspi R, Billington R, Ferrer L et al (2016) The MetaCyc database of metabolic pathways and enzymes and the BioCyc collection of pathway/genome databases. Nucleic Acids Res 44:D471-D480. doi:10.1093/nar/gkt1103

Gordon O, Slenters TV, Brunetto PS et al (2010) Silver coordination polymers for prevention of implant infection: thiol interaction, impact on respiratory chain enzymes, and hydroxyl radical induction. Antimicrob Agents Ch 54:4208-4218. doi:10.1128/AAC.01830-09

Grigor'eva A, Saranina I, Tikunova N, Safonov A, Timoshenko N, Rebrov A, Ryabchikova E (2013) Fine mechanisms of the interaction of silver nanoparticles with the cells of Salmonella typhimurium and Staphylococcus aureus. Biometals 26:479-488. doi:10.1007/s10534-013-9633-3

Gurunathan S, Jeong JK, Han JW, Zhang XF, Park JH, Kim JH (2015) Multidimensional effects of biologically synthesized silver nanoparticles in Helicobacter pylori, Helicobacter felis, and human lung (L132) and lung carcinoma A549 cells. Nanoscale Res Lett 10:1. doi:10.1186/s11671-015-0747-0
Jain N, Bhargava A, Majumdar S, Tarafdar JC, Panwar J (2011) Extracellular biosynthesis and characterization of silver nanoparticles using Aspergillus flavus NJP08: a mechanism perspective. Nanoscale 3:635-641. doi:10.1039/c0nr00656d

Jeevan P, Ramya K, Rena AE (2012) Extracellular biosynthesis of silver nanoparticles by culture supernatant of Pseudomonas aeruginosa. Indian J Biotechnol 11:72-76

Jeyaraj M, Varadan S, Anthony KJP, Murugan M, Raja A, Gurunathan S (2013) Antimicrobial and anticoagulation activity of silver nanoparticles synthesized from the culture supernatant of Pseudomonas aeruginosa. J Ind Eng Chem 19:1299-1303. doi:10.1016/j.jiec.2012.12.031

Kanehisa M, Goto S (2000) KEGG: kyoto encyclopedia of genes and genomes. Nucleic Acids Res 28:27-30

Kathiravan V, Ravi S, Ashokkumar S (2014) Synthesis of silver nanoparticles from Melia dubia leaf extract and their in vitro anticancer activity. Spectrochim Acta A 130:116-121. doi:10. 1016/j.saa.2014.03.107

Kharissova OV, Dias HR, Kharisov BI, Pérez BO, Pérez VMJ (2013) The greener synthesis of nanoparticles. Trends Biotechnol 31:240-248. doi:10.1016/j.tibtech.2013.01.003

Kora AJ, Arunachalam J (2011) Assessment of antibacterial activity of silver nanoparticles on Pseudomonas aeruginosa and its mechanism of action. World J Microb Biot 27:1209-1216. doi:10.1007/s11274-010-0569-2

Kuhn M, Szklarczyk D, Pletscher-Frankild S et al (2013) STITCH 4: integration of protein-chemical interactions with user data. Nucleic Acids Res 42:D401-D407. doi:10.1093/nar/gkt1207

Kumar CG, Mamidyala SK (2011) Extracellular synthesis of silver nanoparticles using culture supernatant of Pseudomonas aeruginosa. Colloid Surface B 84:462-466. doi:10.1016/j.colsurfb. 2011.01.042

Lara HH, Ayala-Nunez NV, Turrent LCI, Padilla CR (2010) Bactericidal effect of silver nanoparticles against multidrugresistant bacteria. World J Microb Biot 26:615-621. doi:10. 1007/s11274-009-0211-3

Lara HH, Garza-Trevino EN, Ixtepan-Turrent L, Singh DK (2011) Silver nanoparticles are broad-spectrum bactericidal and virucidal compounds. J Nanobiotechnology 9:30. doi:10.1186/14773155-9-30

Le Ouay B, Stellacci F (2015) Antibacterial activity of silver nanoparticles: a surface science insight. Nano Today 10:339-354. doi:10.1016/j.nantod.2015.04.002

Lemire JA, Harrison JJ, Turner RJ (2013) Antimicrobial activity of metals: mechanisms, molecular targets and applications. Nat Rev Microbiol 11:371-384. doi:10.1038/nrmicro3028

Li WR, Xie XB, Shi QS, Zeng HY, You-Sheng OY, Chen YB (2010) Antibacterial activity and mechanism of silver nanoparticles on Escherichia coli. Appl Microbiol Biot 85:1115-1122. doi:10. 1007/s00253-009-2159-5

Li WR, Xie XB, Shi QS, Duan SS, Ouyang YS, Chen YB (2011) Antibacterial effect of silver nanoparticles on Staphylococcus aureus. Biometals 24:135-141. doi:10.1007/s10534-0109381-6

Mishra G, Dash B, Pandey S, Mohanty PP (2013) Antibacterial actions of silver nanoparticles incorporated $\mathrm{Zn}-\mathrm{Al}$ layered double hydroxide and its spinel. J Environ Chem Eng 1:1124-1130. doi:10.1016/j.jece.2013.08.031

Mohanpuria P, Rana NK, Yadav SK (2008) Biosynthesis of nanoparticles: technological concepts and future applications. J Nanopart Res 10:507-517. doi:10.1007/s11051-007-9275-X

Muniyappan N, Nagarajan N (2014) Green synthesis of silver nanoparticles with Dalbergia spinosa leaves and their applications in biological and catalytic activities. Process Biochem 49:1054-1061. doi:10.1016/j.procbio.2014.03.015 
Pelgrift RY, Friedman AJ (2013) Nanotechnology as a therapeutic tool to combat microbial resistance. Adv Drug Deliver Rev 65:1803-1815. doi:10.1016/j.addr.2013.07.011

Rai M, Yadav A, Gade A (2009) Silver nanoparticles as a new generation of antimicrobials. Biotechnol Adv 27:76-83. doi:10. 1016/j.biotechadv.2008.09.002

Rai M, Kon K, Ingle A, Duran N, Galdiero S, Galdiero M (2014) Broad-spectrum bioactivities of silver nanoparticles: the emerging trends and future prospects. Appl Microbiol Biot 98:1951-1961. doi:10.1007/s00253-013-5473-x

Sadhasivam S, Shanmugam P, Yun K (2010) Biosynthesis of silver nanoparticles by Streptomyces hygroscopicus and antimicrobial activity against medically important pathogenic microorganisms. Colloid Surface B 81:358-362. doi:10.1016/j.colsurfb.2010.07.036

Saier MH, Tran CV, Barabote RD (2006) TCDB: the Transporter Classification Database for membrane transport protein analyses and information. Nucleic Acids Res 34:D181-D186

Shivaji S, Madhu S, Singh S (2011) Extracellular synthesis of antibacterial silver nanoparticles using psychrophilic bacteria. Process Biochem 46:1800-1807. doi:10.1016/j.procbio.2011.06. 008
Singh SK, Roberts SA, McDevitt SF et al (2011) Crystal structures of multicopper oxidase cueO bound to copper (I) and silver (I) functional role of a methionine-rich sequence. J Biol Chem 286:37849-37857. doi:10.1074/jbc.M111.293589

Vidhu V, Philip D (2014) Spectroscopic, microscopic and catalytic properties of silver nanoparticles synthesized using Saraca indica flower. Spectrochim Acta A 117:102-108. doi:10.1016/ j.saa.2013.08.015

Wei X, Luo M, Li W et al (2012) Synthesis of silver nanoparticles by solar irradiation of cell-free Bacillus amyloliquefaciens extracts and $\mathrm{AgNO}_{3}$. Bioresource Technol 103:273-278. doi:10.1016/j. biortech.2011.09.118

World Health Organization (2015) Global antimicrobial resistance surveillance system: manual for early implementation. World Health Organization

Yehia RS, Al-Sheikh H (2014) Biosynthesis and characterization of silver nanoparticles produced by Pleurotus ostreatus and their anticandidal and anticancer activities. World J Microb Biot 30:2797-2803. doi:10.1007/s11274-014-1703-3 